\title{
The importance of ROE for calculating EVA Equity: the case of Motor Jikov Strojírenská,
} a.s.

\author{
Jan Mareček ${ }^{1}$, Zuzana Rowland ${ }^{2, *}$ \\ ${ }^{1}$ Institute of Technology and Business, School of Expertness and Valuation, Okruzni 517/10, 37001 \\ Ceske Budejovice, Czech Republic \\ ${ }^{2}$ University of Žilina, Faculty of Operation and Economics of Transport and Communications, \\ Univerzitná 8215/1, 01026 Žilina, Slovakia
}

\begin{abstract}
A remarkable success depends on a variety of factors, one of which is the ability to motivate the employees, increasing motivation of managers, measuring business processes and measuring and observing values of the company. The tangible results are also shown by the indicator of return on equity (ROE). The article aims at reflecting the importance of ROE for the EVA Equity (economic value added for shareholders) calculation of Motor Jikov Strojírenská, a.s. The data come from Albertina database. These are details of financial statements from 2000-2015. As a matter of fact, weighted average costs of capital, alternative cost value of equity capital and EVA Equity are calculated. Software Statistica and its sophisticated tool data mining - automated neural networks was used for finding a correlation between EVA Equity indicator and ROE. In addition, 10,000 neural networks were generated, five of which with the best results have been stored. The results show that EVA Equity is not dependent on the ROE rate.

Key words: return on equity (ROE), economic value added for shareholders (EVA Equity), correlation, company management, artificial neural networks
\end{abstract}

\section{Introduction}

The ability to motivate the employees to the greatest extent is one of the most important factors. For that purpose, many coherent motivational theories were developed in time. These theories help the company get the maximum out of its employees [1].

Increasing motivation of managers is a most significant factor for companies [2]. developed a theory which generates motivation of managers, i.e. 'Motivational Factor Inventory' (MFI). MFI consists of 47 items grouped into 6 motivational aspects (human interaction, task, general working conditions, strengthening personal development and compensation). The results showed that MFI constitutes a sophisticated tool for motivating managers. Hawthorne Effect may be also considered as a coherent theory. This theory

\footnotetext{
* Corresponding author: rowland@mail.vstecb.cz
} 
suggests that employees are more productive upon knowing of their work being measured and analysed. In order to motivate the employees for higher performance, they require appropriate recognition for the good job and assurance that their opinion will be taken into account [3]. Maslow's hierarchy of needs [4], theory X and Y [5] and other theories also rank among motivational theories. All these methods help to the overall growth in the value of the business.

Apart from motivation of managers and employees, measuring the performance of business processes also comprises an important factor. This activity became a central topic not only in academic, but also in business sector, since organizations are required to produce concrete and tangible results [6]. According to the modern scientific literature, the most cited models come from measuring performance from Balanced Scorecard Company, model EFQ etc. However, models focused on the whole company and models focused on a single business process must be discriminated [7].

In addition, shareholders must constantly measure and observe the company value. Above all, creating a capital budget belongs among ingenious devices which measure the business performance [8]. This applies to selecting investment projects which maximize the value of the shareholders [9]. A benchmark which enables a direct comparison of the company performance with another similar, prosperous company [10], key indicators of the productivity for clarifying business strategies [11]. Balanced Scorecard Method focused on strategic organization management [12]. Six Sigma Method focused on permanently improving all organization processes and eliminating procedural errors [13].

In addition, an indicator of return on equity (ROE) is also essential for the company management. It shows how much of the net profit falls on one Czech Crown of the invested capital [14]. The ROE indicator is calculated as a ration of the net profit and equity capital [15]. The ROE indicator is essential mainly for shareholders, co-partners and other investors [16]. Kyriazis and Anastassis [17] investigated the relative explanatory power of the EVA model with respect to stock returns and firms' market value, compared to established accounting variables - net income or operating income. Their results showed that EVA, even though useful as a performance evaluation tool, need not necessarily be more correlated with shareholder's value than established accounting variables. The results showed that firms using EVA exhibit a higher percentage of institutional ownership and a lower percentage of insider ownership than non-adopters [18]. Prospector companies tend to use EVA less than defender firms and providing appropriate incentives may be more complex than the developers of EVA imply. Rowland [19] decomposed EVA Equity, which is viewed as the strategical goal of a company, into partial indicators that can be incorporated into a company's tactical plan in the form of operative plan indicators.

Therefore, the article focuses on appreciating the importance of ROE for calculating EVA Equity of the particular company.

The hypothesis has been formulated as follows: EVA Equity value is dependent on ROE value at least from $70 \%$.

\section{Data and methods}

We have the financial statements of Motor Jikov Strojírenská, a.s. at our disposal. The data have been derived from Albertina database applying to financial statements from 2000 to 2015. The data will be compiled to a statistical table. Each line will contain information about one particular year. The information about financial statements will be drawn up in columns. In addition, Economic Value Added for shareholders (EVA Equity) in each analysed year will be added in the next step.

The sources of the particular data about financial statements are suggested in the table 1 . 
Tab. 1. The sources of the particular data from financial statements

\begin{tabular}{|l|l|l|}
\hline \multicolumn{1}{|c|}{ Name } & \multicolumn{1}{|c|}{ Statement } & \multicolumn{1}{c|}{ Item } \\
\hline Capital & Balance & (C.I+C.III+C.IV+D.I.2) - \\
& & B.III+B.IV.2+B.IV.3+C.I.1) \\
\hline Activity total & Assets balance & A + B + C + D \\
\hline Stock & Assets balance & C.I. \\
\hline Debt & Assets balance & C.III. \\
\hline Short-term financial assets & Assets balance & C.IV. \\
\hline Current assets & Assets balance & C \\
\hline Equity capital & Liability balance & A. \\
\hline Bonds and bills of exchange & Liability balance & B.II.6 a B.II.7 \\
\hline Common and financial help & Liability balance & B.IV.2 a B.IV.3 \\
\hline Long-term help & Liability balance & B.IV.1 \\
\hline Short-term commitments & Liability balance & B.III \\
\hline Retained earnings & Liability balance & A.III.2+A.IV+A.V \\
\hline Debt & Liability balance & B \\
\hline Short-term debt & Liability balance & B.III + B.IV \\
\hline Money sources & Liability balance & A + B.IV. + B.II.6 + B.III.9 \\
\hline Revenues and sold goods & Profit and loss & I. \\
\hline Cost of sold goods & Profit and loss & A. \\
\hline Productivity & Profit and loss & II. \\
\hline Productivity consumption & Profit and loss & B. \\
\hline Personal expenses & Profit and loss & C. \\
\hline Write-offs & Profit and loss & E. \\
\hline Interest expenses & Profit and loss & N. \\
\hline Gross yields for the accounting period & Profit and loss & $* * *$ \\
\hline Total yields & Profit and loss & I. + II. + ... + XIII. \\
\hline Total costs & Profit and loss & A + B + .. + T \\
\hline Profit before interest and tax & Profit and loss & $* * *+$ S+ Q + N \\
\hline Revenues & Profit and loss & I. + II.1. \\
\hline & & \\
\hline
\end{tabular}

It requires an exact calculation of weighted average costs of the capital [20]:

$$
W A C C=r_{f}+r_{L A}+r_{\text {entreprenarship }}+r_{\text {FinStab }}
$$

Where:

$r_{f}$

$r_{L A}$
$r_{\text {entrepreneurship }}$
$r_{\text {FinStab }}$ risk free yield derived from the interested rate of ten-year government bond,

function of indicators defining the liquidity,

function of indicators defining the creation of, production power, function of indicators defining the relations between, company assets and sources of their covering.

Subsequently, a value of the rate of equity will be set [20]: 


$$
r_{e}=\frac{W A C C * \frac{U Z}{A}-(1-d) * \frac{U}{B L+B} *\left(\frac{U Z}{A} * \frac{E}{A}\right)}{\frac{E}{A}}
$$

Where:

$r_{e}$
$W A C C$
$U Z$
$A$
$E$
$B L$
$B$
$U / B L+B$
$d$

rate of equity, weighted average cost of capital, money sources (equity capital, interest-bearing debt), assets, equity capital, bank loans, bonds, interest rate $-i$ (interest), the rate of income tax $-t(\operatorname{tax})$.

Economic value added for shareholders will be derived from the relation [20]:

$$
\text { EVA Equity }=\left(R O E-r_{e}\right) * E
$$

Where:

$R O E$

return on equity.

Subsequently, the table will be imported to Statistica Software of DELL Company in version 12. We will be looking for the extent of correlation of the indicator of EVA Equity and ROE.

Firstly, data mining, automated neural networks (ANNs) and regression will be dealt with. EVA Equity will be used as a dependent variable, whereas ROE will be employed as an independent variable. The data set will be divided into three aggregates - training, testing and validating. The first group will contain $70 \%$ of input figures. Neural structures will be generated from the training data set. The two remaining groups will include $15 \%$ of input figures. Groups may provide the reliability verification of the neural structures i.e. the found model [21]. 10,000 neural networks will be generated, the best five of which will be preserved $^{1}$. The hidden layer of the multi-layer perceptron network (MLP) will contain from 2 to 10 neurons. In case of the neural network of radial basic function, the hidden layer will include only 5 to 15 neurons. Multiple perceptron networks will be considered for these distribution functions in the hidden layer and the output layer:

- Linear,

- Logistic,

- Atanh,

- Exponential,

- Sinus.

The picture 1 illustrates a pyramid disintegration of ROE indicator in INFA Model the Neumaiers.

In case the correlation of EVA Equity and ROE is high, the correlation of constituent variables entering ROE calculation should be systematically analysed. In case of success

\footnotetext{
${ }^{1}$ The method of least squares will be used. Generation of networks will be finished when there is no improvement, i.e. when there is no reduction in the sum of the squares. We thus retain the neural structures whose sum of squares of residues to actual development of gold will be as low as possible (zero, ideally).
} 
and the high correlation between EVA Equity and the selected indicator entering EVA Equity calculation, a future development of economic value added for owners of the indicator may be predicted. In this way, a simple tool for indicating the state of the company will be created. The picture 1 shows variables entering ROE calculation which apply only to the net return on equity, EBIT (i.e. profit without interests and taxing), added value, personal expenses etc.

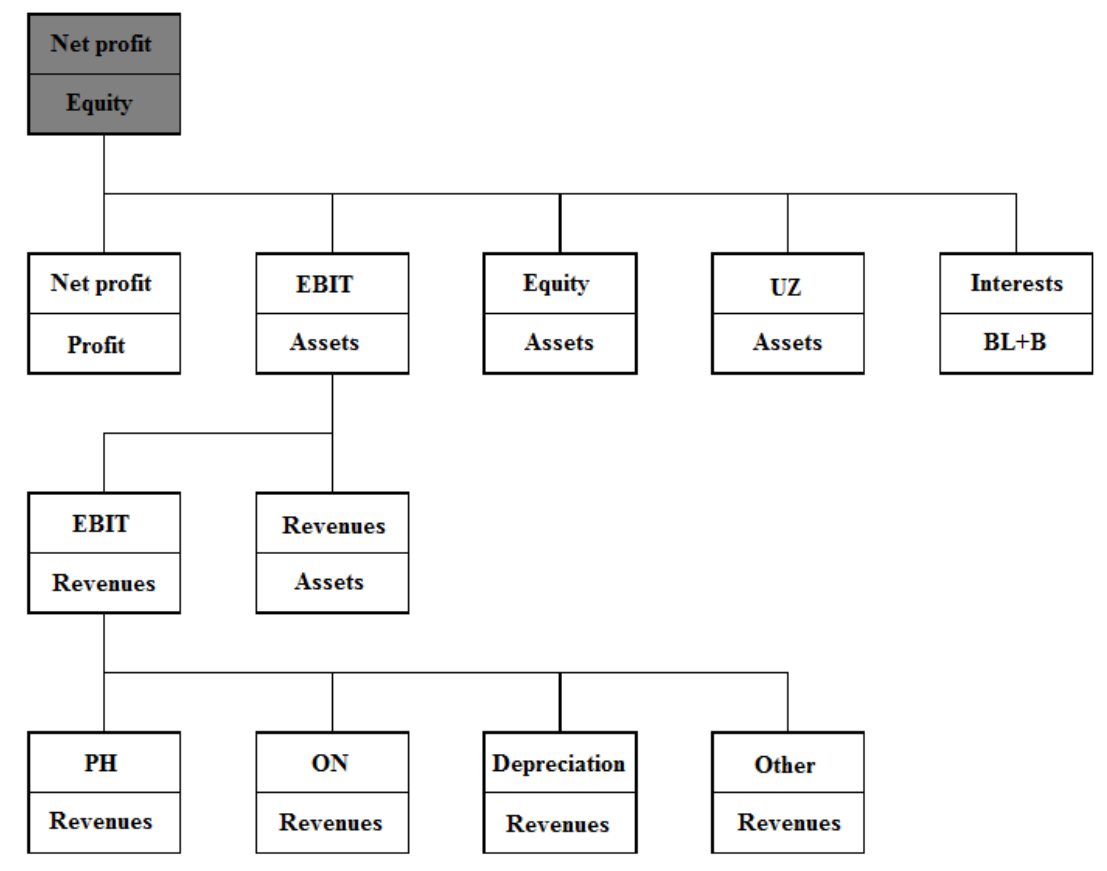

Picture 1. Disintegration of ROE indicator in INFA Model

\section{Results}

The table 3 suggests basic description of the data sets. It analyses the minimum, maximum and standard deviation of input data. The data are analysed in regard to the training, testing and validating data aggregate. 
Table 2. Statistic characteristics entering the calculation

\begin{tabular}{|l|r|r|}
\hline \multirow{2}{*}{ Characteristics } & ROE (\%) & \multicolumn{1}{c|}{$\begin{array}{c}\text { EVA } \\
\text { (thousands } \\
\text { CC) }\end{array}$} \\
\hline Minimum (Training) & \multicolumn{1}{c|}{ Input var. } & \multicolumn{1}{c|}{ Output } \\
\hline Maximum (Training) & -19.69 & 9.36 \\
\hline Average (Training) & 13.25 & 34811.48 \\
\hline Standard deviation (Training) & 0.47 & 10214.67 \\
\hline Minimum (Testing) & 10.1829 & 11162.02 \\
\hline Maximum (Testing) & 3.11 & 2100.99 \\
\hline Average (Testing) & 10.52 & 3561.82 \\
\hline Standard deviation (Testing) & 6.815 & 2831.4 \\
\hline Minimum (Validating) & 5.2397 & 1032.96 \\
\hline Maximum (Validating) & -80.48 & 10.8 \\
\hline Average (Validating) & 2.66 & 20991.66 \\
\hline Standard deviation (Validating) & -38.91 & 10501.23 \\
\hline Minimum (Overall) & 51.21 & 14810.28 \\
\hline Maximum (Overall) & -80.48 & 9.36 \\
\hline Average (Overall) & 13.25 & 34811.48 \\
\hline Standard deviation (Overall) & -3.6594 & 9327.58 \\
\hline
\end{tabular}

Deviations of the individual characteristics for three different data sets suggest three markedly different data sets. However, the result will be rather negative. For example, take the minimum ROE of each data set. The minimum of the training data set was spotted at the value of 19.69 , testing data set at 3.11 and validating data set at -80.48 . The differences are big, especially the data interval, of which the maximum value in each data set is (13.25; 10.52 or 2.66$)$.

Acquired and at the same time preserved neural structures are suggested in table 3.

Table 3. Generated and preserved neural networks

\begin{tabular}{|r|l|r|r|r|r|r|r|r|r|r|}
\hline Index & Network & $\begin{array}{c}\text { Train. } \\
\text { perf. }\end{array}$ & $\begin{array}{c}\text { Test. } \\
\text { perf. }\end{array}$ & $\begin{array}{c}\text { Valid. } \\
\text { perf. }\end{array}$ & $\begin{array}{c}\text { Training } \\
\text { error }\end{array}$ & $\begin{array}{c}\text { Testing } \\
\text { error }\end{array}$ & $\begin{array}{c}\text { Valid. } \\
\text { error }\end{array}$ & $\begin{array}{c}\text { Training } \\
\text { algorithm }\end{array}$ & $\begin{array}{c}\text { Error } \\
\text { function }\end{array}$ & $\begin{array}{c}\text { Activation } \\
\text { hidden } \\
\text { layer }\end{array}$ \\
\hline 1 & $\begin{array}{l}\text { MLP } \\
1-2-1\end{array}$ & 0.355191 & 1 & 1 & 50000528 & 16465105 & 32538328 & BFGS 0 & Total sq. & Logistic \\
\hline 2 & $\begin{array}{l}\text { RBF } \\
1-5-1\end{array}$ & 0.718692 & -1 & 1 & 27608817 & 9556342 & 2586642 & RBFT & Total sq. & Gauss \\
\hline 3 & $\begin{array}{l}\text { MLP } \\
1-3-1\end{array}$ & 0.310595 & 1 & 1 & 51609109 & 12888885 & 44741428 & BFGS 0 & Total sq. & Logistic \\
\hline 4 & $\begin{array}{l}\text { RBF } \\
1-5-1\end{array}$ & 0.584094 & -1 & 1 & 40170595 & 2036325 & 64055783 & RBFT & Total sq. & Gauss \\
\hline 5 & $\begin{array}{l}\text { RBF } \\
1-5-1\end{array}$ & 0.583614 & -1 & 1 & 37836882 & 3172625 & 53546896 & RBFT & Total sq. & Gauss \\
\hline
\end{tabular}

Two MLP neural layers were preserved, i.e. the first and the third network. Both of them activate inner neural layers by Logistic Function and outer neural layers by Sinus Function. Algorithm Quasi - Newton was used for constructing both neural networks. Furthermore, three RBF networks were preserved. All networks activate the hidden neural layer by Gauss Curve and outer neural network by Identity.

The value of individual networks is dependent mainly on their performance. This is measured by the correlation coefficient. Values of correlation coefficients of individual networks and data sets are depicted in Table 4. 
Table 4. Correlation coefficients of neural networks according to the input data sets

\begin{tabular}{|l|r|r|r|}
\hline Neural network & Training set & Testing set & Validating set \\
\hline 1.MLP 1-2-1 & 0.355191 & 1 & 1 \\
\hline 2.RBF 1-5-1 & 0.718692 & -1 & 1 \\
\hline 3.MLP 1-3-1 & 0.310595 & 1 & 1 \\
\hline 4.RBF 1-5-1 & 0.584094 & -1 & 1 \\
\hline 5.RBF 1-5-1 & 0.583614 & -1 & 1 \\
\hline
\end{tabular}

As a matter of fact, we are looking for a neural structure with an optimal value of the correlation coefficient in all data sets while considering their identical amount. In regard to the formulated hypothesis, we are looking for a correlation coefficient above 0.7 , which applies only to network No. 2. However, a value of correlation coefficient -1 occurs in the testing data set, the fact of which means that the indirect proportion is to be dealt with. On the other hand, correlation coefficient 1 occurs in the validating data set.

The whole situation is illustrated in Table 5.

Table 5. Statistic characteristics of predictions

\begin{tabular}{|c|c|c|c|c|c|}
\hline Characteristic & 1.MLP 1-2-1 & 2.RBF 1-5-1 & 3.MLP 1-3-1 & 4.RBF 1-5-1 & 5.RBF 1-5-1 \\
\hline $\begin{array}{l}\text { Minimal prediction } \\
\text { (Training) }\end{array}$ & 4476.7 & 304.5 & 5615.3 & 2800.3 & 728.1 \\
\hline $\begin{array}{l}\text { Maximal prediction } \\
\text { (Training) }\end{array}$ & 16157.5 & 28353 & 16811.9 & 31470.2 & 21751.2 \\
\hline $\begin{array}{l}\text { Minimal prediction } \\
\text { (Testing) }\end{array}$ & 6320.4 & -1320.3 & 6576.3 & 3889.3 & 2779.8 \\
\hline $\begin{array}{l}\text { Maximal prediction } \\
\text { (Testing) }\end{array}$ & 10494.1 & 5894.5 & 9176.8 & 4936.1 & 5576.5 \\
\hline $\begin{array}{l}\text { Minimal prediction } \\
\text { (Validating) }\end{array}$ & 10705.4 & -538 & 9333.8 & 4501.9 & 4122.7 \\
\hline $\begin{array}{l}\text { Maximal prediction } \\
\text { (Validating) }\end{array}$ & 17019.4 & 17822.2 & 30585.8 & 5627.6 & 6946 \\
\hline $\begin{array}{l}\text { Minimal residua } \\
\text { (Training) }\end{array}$ & -13898.4 & -12211.6 & -12372.1 & -10909.4 & -17995.7 \\
\hline $\begin{array}{l}\text { Maximal residua } \\
\text { (Training) }\end{array}$ & 21356.6 & 13415.3 & 22979 & 20218.9 & 13060.2 \\
\hline $\begin{array}{l}\text { Minimal residua } \\
\text { (Testing) }\end{array}$ & -6932.3 & -3793.5 & -5614.9 & -2835.2 & -3475.5 \\
\hline $\begin{array}{l}\text { Maximal residua } \\
\text { (Testing) }\end{array}$ & -42194 & 4882.1 & -4475.3 & -327.4 & 782.1 \\
\hline $\begin{array}{l}\text { Minimal residua } \\
\text { (Validating) }\end{array}$ & -10694.6 & 548.8 & -9594.1 & -4491.1 & -4111.9 \\
\hline $\begin{array}{l}\text { Maximal residua } \\
\text { (Validating) }\end{array}$ & 3972.2 & 3169.4 & -9323 & 15364 & 14045.6 \\
\hline $\begin{array}{l}\text { Minimal standard } \\
\text { residua (Training) }\end{array}$ & -2 & -2.3 & -1.7 & -1.7 & -2.9 \\
\hline $\begin{array}{l}\text { Maximal standard } \\
\text { residua (Training) }\end{array}$ & 3 & 2.6 & 3.2 & 3.2 & 2.1 \\
\hline $\begin{array}{l}\text { Minimal standard } \\
\text { residua (Testing) }\end{array}$ & -1.7 & -1.2 & -1.6 & -2 & -2 \\
\hline $\begin{array}{l}\text { Maximal standard } \\
\text { residua (Testing) }\end{array}$ & -1 & 1.6 & -1.2 & -0.2 & 0.4 \\
\hline $\begin{array}{l}\text { Minimal standard } \\
\text { residua (Validating) }\end{array}$ & -1.9 & 0.3 & -1.4 & -0.6 & -0.6 \\
\hline $\begin{array}{l}\text { Maximal standard } \\
\text { residua (Validating) }\end{array}$ & 0.7 & 2 & -1.4 & 1.9 & 1.9 \\
\hline
\end{tabular}


The table illustrates statistic characteristics of predictions. The table suggests big differences between the predictions of individual neural structures. This is still acceptable since not all the networks are applicable in practice. Nevertheless, dramatic differences between identical characteristics of the same network according to the individual data sets may be seen. These are again very big, although residua, of which the sum is close to zero and there are no big differences between preserved networks, may be excluded. Table 6 shows results of the sensitivity analysis.

Table 6. Sensitivity analysis

\begin{tabular}{|l|r|}
\hline & ROE (\%) \\
\hline 1.MLP 1-2-1 & 1.271928 \\
\hline 2.RBF $1-5-1$ & 2.665624 \\
\hline 3.MLP $1-3-1$ & 1.15558 \\
\hline 4.RBF $1-5-1$ & 1.456952 \\
\hline 5.RBF $1-5-1$ & 1.684762 \\
\hline Average & 1.646969 \\
\hline
\end{tabular}

Except for No. 3, the analysis indicates positive results. Changes in ROE correlate with a dramatic shift in EVA Equity.

The hypothesis in the introduction has been formulated as follows: EVA Equity value depends on ROE value at least from $70 \%$; thus, the hypothesis has been rejected. Broadly speaking, EVA Equity does not depend on ROE value in its calculation.

\section{Conclusion}

The aim of this article was to appreciate the importance of ROE for the calculation of EVA Equity of the specific company.

Based on the calculation, we conclude that EVA Equity does not depend on ROE (at least in case of Motor Jikov Strojírenská, a.s.). In this case, it is not possible to carry on in the analysis of variables entering ROE calculation and simplify EVA Equity calculation, or alternatively, find the motion indicator of EVA Equity.

All the same, as long as we analyse the way EVA Equity was calculated, the conclusion is not very logical and cannot be agreed with. More likely, a distinct lack of data may be blamed for, or alternatively, data errors which entered the calculation. ROE is useless predictor of EVA in particular companies. In our case there was no relationship in other the relationship is to be found. There is most likely a third variable which influences the relationship between ROE and EVA. Still, the situation may be successfully dealt with. The data sets of companies might be used for further calculations; and in this way, on the one hand they may develop the data base for the calculation and on the other, they may generalize the result at a certain level.

\section{References}

1. P. Rong, Analysis and Application of Modern Motivation Theory in Public Relations Management. Proceedings of the $11^{\text {th }}$ International Conference on Innovation and Management, Vaasa, Finland, 1010-1014 (2014) 
2. S. Seiler, B. Lent, M.Pinkowska, M. Pinazza, An integrated model of factors influencing project managers' motivation - Findings from a Swiss Survey. International Journal of Project Management, 30(1), 60-72 (2012)

3. H. Lück, E. Helmut, The Hawthorne effect - an effect fo many occasions? [Der Hawthorne-Effekt - ein Effekt für viele Gelegenheiten?]. Group dynamics and organizational consulting [Gruppendynamik und Organisationsberatung], 40(1), 102114 (2019)

4. V. Pereira, M. G. C. Campos and G. Camarini, Maslow's Theory of Motivation Hierarchy of Needs: Results from Construction Operational Workers in São Paulo City, Brazil. Applied Mechanics and Materials, 174-177, 2339-2342 (2012)

5. P. M. Medeiros, N.M.S. Galvão, J.G.N. Araújo, U.C.T. Lagioia, A.P.S. Ferreira, Perception of Accounting Sciences Students Regarding Behavior in the Workplace: A Study Based on Theory X and Y. [Percepção dos Discentes de Ciências Contábeis Quanto ao Comportamento no Ambiente de Trabalho: Um Estudo Baseado na Teoria $\mathrm{X}$ e Y]. Journal of Management, Finance and Accounting [Revista de Gestão, Finanças e Contabilidade], 6(1), 152-172 (2016)

6. A. Van Looy, A. Shafagatova, Business process performance measurement: a structured literature review of indicators, measures and metrics. SpringerPlus, 5(1), (2016)

7. V. Burja, R. Mărginean, The Study of Factors that may Influence the Performance by the Dupont Analysis in the Furniture Industry. Procedia Economics and Finance, 16, 213-223 (2014)

8. A. Kasych, M. Vochozka, Theoretical and methodical principles of managing enterprise sustainable development. Marketing and Management of Innovations, (2), 298-304 (2017)

9. G. Andor, S.K. Mohanty, T. Toth, Capital budgeting practices: A survey of Central and Eastern European firms. Emerging Markets Review, 23, 148-172 (2015)

10. M. Tvaronavičienè, K. Razminienè, L. Piccinetti, Cluster efficiency study through benchmarking. Entrepreneurship and Sustainability Issues, 3(2), 120-128 (2015)

11. J. Sofiyabadi, B.Kolahi, Ch. Valmohammadi, Key performance indicators measurement in service business: a fuzzy VIKOR approach. Total Quality Management, 27(9-10), 1028-1042 (2015)

12. A. H. Aly, M. E. Mansour, Evaluating the sustainable performance of corporate boards: the balanced scorecard approach. Managerial Auditing Journal, 32(2), 167-195 (2017)

13. A. Pugna, R. Negrea, S. Miclea, Using Six Sigma Methodology to Improve the Assembly Process in an Automotive Company. Procedia - Social and Behavioral Sciences, 221, 308-316 (2016)

14. V. Stehel, M. Vochozka, the analysis of the economical value added in transport. Nase More, 63(3), 185-188 (2016)

15. A. Kijewska, Determinants of the return on equity ratio (ROE) on the example of companies from metallurgy and mining sector in Poland. Metalurgija - Sisak then Zagreb, 55(2), 285-288 (2016)

16. I. Berzkalne, E. Zelgalve, Return on equity and company characteristics: an empirical study of industries in Latvia. Proceedings of the $8^{\text {th }}$ International Days of Statistics and Economics, Prague, Czech republic, 94-103 (2014) 
17. D. Kyriazis, Ch. Anastassis, The Validity of the Economic Value Added Approach: an Empirical Application. European Financial Management, 13(1), 71-100 (2007)

18. L. Lovata, M. Costigan, Empirical analysis of adopters of economic value added. Management Accounting Research, 13(2), 215-228 (2002)

19. Z. Rowland, Decomposition of EVA Equity to the Sub-operational Plans of a Company. Littera Scripta, 9(3), 52-65 (2016)

20. I. Neumaierová, I. Neumaier, Financial analysis of industry and construction in 2007 [Finanční analýza průmyslu a stavebnictví za rok 2007]. Analysis of the Ministry of Industry and Trade [Analýzy MPO], 1, 1-187, (2008)

21. M. Vochozka, Decomposition of a main objective of an international company set with the help of artificial neural networks into daily plans. Proceedings of the $16^{\text {th }}$ International Scientific Conference on Globalization and its Socio-economic Consequences, Zilina, Slovakia, 2383-2390 (2016) 